\title{
RADIO-ECHO SOUNDING OF THE LAMBERT GLACIER BASIN
}

\author{
By V. I. Morgan and W. F. Budd \\ (Antarctic Division, Department of Science, 568 St. Kilda Road, Melbourne, Victoria, \\ Australia)
}

\begin{abstract}
Several seasons of aerial ice-thickness soundings over the region of the Prince Charles Mountains, the Lambert Glacier system, the Amery Ice Shelf, and their drainage basin in east Antarctica have now been completed. The measurements provide detailed maps of surface topography and ice thickness over an area of about $2 \times 10^{5} \mathrm{~km}^{2}$. The equipment used consisted of a $100 \mathrm{MHz}$ echo sounder designed and constructed by Antarctic Division and carried in a Pilatus Porter aircraft. ERTS imagery provides a valuable background for portraying the echo-sounding results. These results show that an extensive, deep subglacial valley system forms the basis of the large drainage basin with concave ice surface topography which channels the ice flow into the Amery Ice Shelf. Deep glacial streams penetrate a long way into the ice-sheet basin. The rock relief is considerable, varying from $3000 \mathrm{~m}$ above (present) sea-level to $2000 \mathrm{~m}$ below sea-level. A very deep subglacial trench exists in the region of the confluence of the Fisher, Mellor, and Lambert Glaciers where the ice thickness reaches $2500 \mathrm{~m}$. The low surface slope and high ice velocity are suggestive of high melt production in this region. The strong echo, together with the high bedrock
\end{abstract} back-slope, suggests that the deep trench may contain a basal melt lake.

RÉsumé. Sondage par radio-echo du bassin du Glacier Lambert. Plusieurs saisons de sondages aériens d'épaisseur de glace ont maintenant été menées à bien sur les régions des Prince Charles Mountains, du système du Lambert Glacier, de l'Amery Ice Shelf et de leur bassin d'alimentation en Antarctique orientale. Les mesures ont permis de dresser des cartes détaillées de la topographie superficielle et de l'épaisseur de la glace sur une étendue d'environ $2 \times 10^{5} \mathrm{~km}^{2}$. L'équipement utilisé consistait en un sondeur à écho $100 \mathrm{MHz}$ conçu et construit par la Division Antarctique et porté par un avion Pilatus. Les images ERTS donnent une base valable pour mettre en évidence les résultats des sondages par écho. Ces résultats montrent qu'un vaste et profond système de vallées sous-glaciaires forme la base d'un vaste bassin d'alimentation, avec une topographie concave de la surface glaciaire, qui canalise l'écoulement de la glace vers l'Amery Ice Shelf. De profonds courants de glace pénètrent sur une grande longueur à l'intérieur du bassin de la banquise. Le relief rocheux est très important, variant de $3000 \mathrm{~m}$ au-dessus du niveau (actuel) de la mer à 2 ooo $\mathrm{m}$ en dessous. Un très profond fossé sous-glaciaire se trouve dans la région de la confluence des glaciers Fisher, Mellor et Lambert avec des profondeurs atteignant $2500 \mathrm{~m}$. La faible pente superficielle de la glace et sa grande vitesse fondent l'hypothèse d'une importante fusion dans cette zone. La netteté de l'écho ainsi que la forte pente du bedrock vers l'amont font penser que le fossé profond peut contenir à la base un lac d'eau de fusion.

Zusammenfassung. Radar-Echolotung des Lambert Glacier Basin. Für das Gebiet der Prince Charles Mountains, des Lambert-Glaciersystems, des Amery Ice Shelf und ihr Einzugsgebiet in der Ostantarktis liegen nunmehr Eisdickenmessungen aus der Luft von mehreren Jahren vor. Die Messungen liefern genaue Karten der Oberfächentopographie und der Eismächtigkeit über ein Gebiet von etwa $2 \times 10^{5} \mathrm{~km}^{2}$. Als Messgerät wurde ein $100 \mathrm{MHz}-$ Echolot benutzt, entworfen und gebaut von der Antarctic Division; getragen wurde es von einem Pilatus-Porter-Flugzeug. ERTS-Bilder dienen als wertvolle Grundlage zur Wiedergabe der Lotungsergebnisse. Diese Ergebnisse zeigen, dass das weite Einzugsgebiet mit nach oben konkaver Eisoberfläche von einem ausgedehnten, tiefen, subglazialen Talsystem gebildet wird; von dort wird der Eisfluss in das Amery Ice Shelf geleitet. Tiefe Eisströme reichen weit in das Becken der Eisdecke hinein. Das Relief des Felsuntergrundes ist beträchtlich; es erstreckt sich von $3000 \mathrm{~m}$ über bis 2 ooo m unter dem (gegenwärtigen) Meeresspiegel. Ein sehr tiefer subglazialer Graben liegt im Gebiet des Zusammenflusses von Fisher, Mellor und Lambert Glaciers; die Eisdicke erreicht dort $2500 \mathrm{~m}$. Die geringe Oberflächenneigung und die hohe Fliessgeschwindigkeit des Eises lassen auf starke Abschmelzung in diesem Gebiet schliessen. Das kräftige Echo zusammen mit dem Gegengefälle des Felsbettes führen zu der Vermutung, dass der tiefe Graben am Untergrund einen Schmelzwassersee enthält.

\section{InTRODUGTION}

The Lambert Glacier and Amery Ice Shelf system drains a large part of the east Antarctic ice sheet through a comparatively narrow outlet. Thus, for mass-balance studies of Antarctica, it is important to know the mass flux through this outlet. This requires detailed measurements of ice thickness and velocity over the region. For this reason an intensive long-term project has been devoted to the study of the Amery Ice Shelf and the Lambert Glacier basin by the Australian National Antarctic Research Expeditions (A.N.A.R.E.). The earlier work on the Amery Ice Shelf has been discussed by Budd (1966) and Budd and others (1967). The most serious gap in this earlier work was the lack of information on the ice thickness. Later 
expeditions have endeavoured to fill this gap. An over-wintering party in 1968 carried out deep core drilling (cf. Morgan, 1972), microclimatology and ice-movement surveys. Further work in the following summers included ground echo-sounding surveys on the Amery Ice Shelf during 1969-70 and aerial sounding in the Lambert Glacier basin during 1971-72, 1973-74 along with an ice-movement survey around the basin. A report on the Amery Ice Shelf Project is in preparation by Budd and others (in preparation). The present paper aims at providing a preliminary survey of the results of this ice thickness sounding in the Lambert Glacier basin. A more extensive report is being prepared by Morgan.

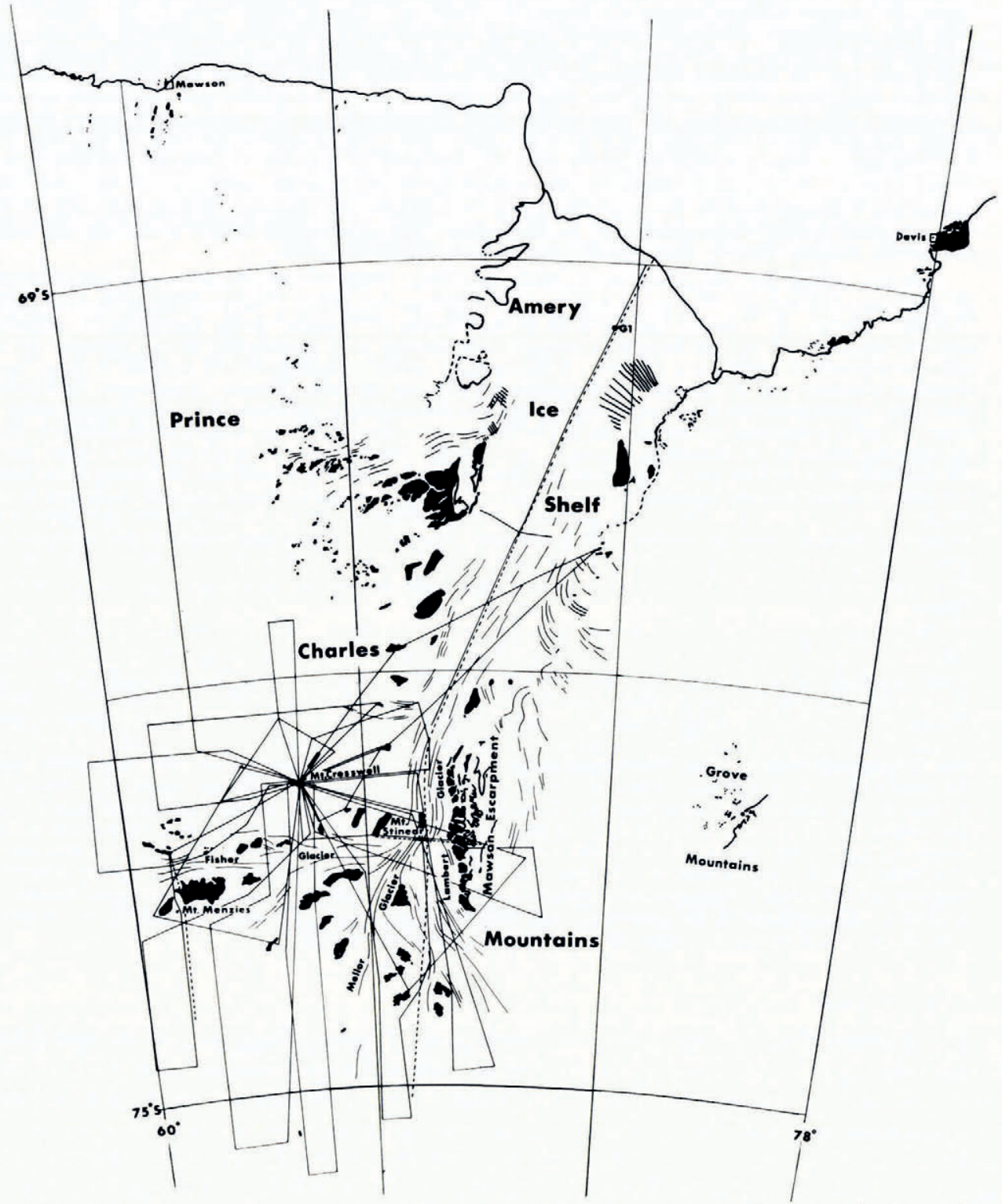

Fig. I. Radio-echo sounding lines in the basin containing the Lambert Glacier and the Amery Ice Shelf. The thickened section of flight line shows the area from which the examples of Figure 7 were taken, with (a) just north of Mt Cresswell and (b) between Mt Stinear and the Mawson Escarpment. The dotted lines show the positions of the profiles of Figures 4, 5 and 6 . 


\section{ERTS IMAGERY BACKGROUND}

Although most of the region of the northern and southern Prince Charles Mountains around the Lambert Glacier basin has been covered by aerial photography, high-detail maps from these photographs are not yet available. The ERTS photographs of the area overlain as a mosaic on I : $10^{6}$ maps have provided a very useful background upon which to draw new information such as flight lines, surface elevations, and ice thickness. The band 7 imagery (near infrared) has been used here with printing aimed at maximum detail for ice and snow. The ERTS photographs show up many important features such as ice flow lines, crevasse zones, rock, moraine, ice domes and ridges. This has been particularly useful for clarifying many features of the ice surface elevations and ice thickness patterns obtained from the aerial sounding.

\section{Sounding Lines AND OpERAtions}

Figure I shows a map of the Amery Ice Shelf-Lambert Glacier basin with all the sounding lines completed to date. The centre-line and cross profiles on the Amery Ice Shelf were carried out by ground survey using motor toboggans and dog sleds. The remaining lines were measured from a Pilatus Porter aircraft. Navigation was primarily controlled by line of sight to mountain features using a drift sight.

Errors in position, which tend to increase as the distance from land marks becomes greater, reach about $5 \mathrm{~km}$ by the end of the longest lines. In order to minimize the radar beam dispersion, the aircraft generally flew at or below $300 \mathrm{~m}$ above the surface. The surface elevation was obtained from a standard radar altimeter $(440 \mathrm{MHz})$ and a barometric altimeter in the aircraft. The base station at Mt Cresswell, which is shown on the map, provided a base reference for altitude. The total distance covered by the lines is about $6900 \mathrm{~km}$, but clear bedrock echoes were not obtained on all flights.

\section{ECHO-SOUNDING EQUIPMENT}

The radio-echo sounder was designed and built by the Antarctic Division and is described in its original form by Bird and others (in press). Some of the characteristics of the preliminary equipment were compared with other systems by Evans (1970). A complete report on the current equipment is in preparation by Bird. Only a brief summary of the main features can be presented here. Table I lists the major technical characteristics of the instrument.

Table I. Teghnical characteristics of Antarctic Division air-borne radio-echo sounder ig69-i974

$\begin{array}{cccccccc}\text { Radio } & \begin{array}{c}\text { Transmitter } \\ \text { pulse power }\end{array} & \text { Bandwidth } & \begin{array}{c}\text { Pulse } \\ \text { duration }\end{array} & \begin{array}{c}\text { Range } \\ \text { accuracy }\end{array} & \begin{array}{c}\text { Systems } \\ \text { performance }\end{array} & \begin{array}{c}\text { Antennae } \\ \text { gain }\end{array} & \text { Power supply } \\ 100 \mathrm{MHz} & 5 \mathrm{~kW} & 10 \mathrm{MHz} & 0.3 \mu \mathrm{s} & 7 \mathrm{~m} & 175 \mathrm{~dB} & \mathrm{II} \mathrm{dB} & 24 \mathrm{~V} \text {, }\end{array}$

Recording: (I) One oscilloscope with range/time display for continuous recording on $35 \mathrm{~mm}$ film.

(2) One oscilloscope with A-scope display for visual monitoring and polaroid photography.

\section{General discussion of Results}

On most occasions the film record enabled clear identification of the bedrock echoes to be made. Some gaps in the record were the result of malfunctions in equipment during preliminary trial flights, but there are areas of major crevassing for which surface losses were so high that, even under the best conditions, bedrock echoes were difficult to obtain. Strong echoes were obtained in the lower reaches of the Lambert Glacier and over the Amery Ice Shelf. These, and the smooth, flat, uniform surface of the lower Lambert Glacier, suggest 
that there could be considerable melt water at the base of the ice. Temperature calculations of Budd and others ([1970], I97I), and the identification of melt lakes beneath the main Antarctic ice sheet (Oswald and Robin, 1973) support this impression.

\section{Reduction METHODS}

On each flight, echo times (and hence ice thickness values) were obtained from the film records at $3 \mathrm{~km}$ intervals. A profile for each flight line was later constructed from these measurements. As the ice surface is smoother, readings every ro $\mathrm{km}$ were found to be sufficient for the construction of elevation profiles. Superimposed on the flight-line maps at $1:{ }^{6} 0^{6}$ scale, these profiles enabled smooth contour maps of surface elevation, ice thickness, and bedrock elevation to be constructed.

Since at this stage we are primarily interested in the major large-scale topography, no attempt has been made to deconvolute echoes over smaller-scale irregularities. To calculate

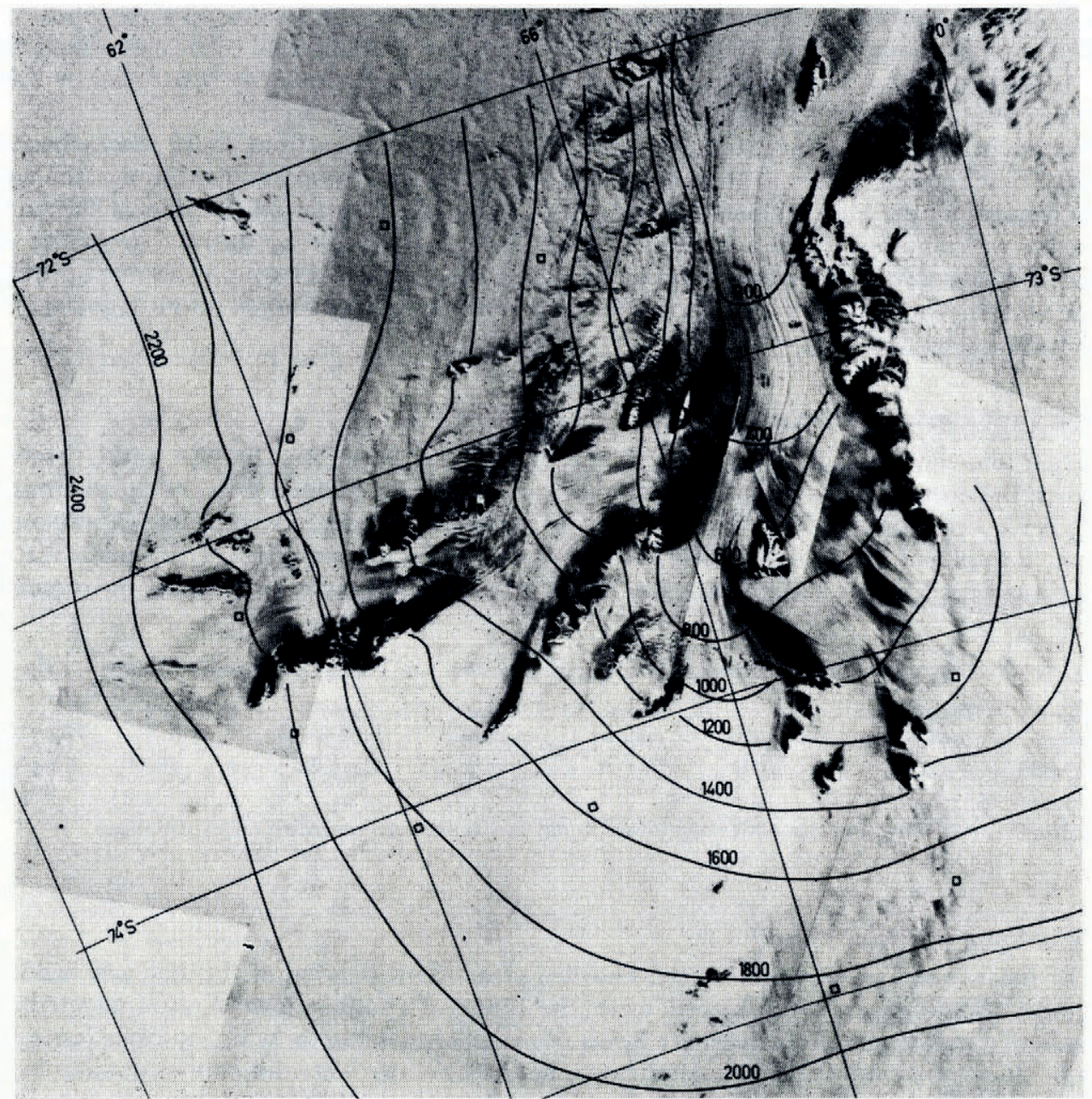

Fig. 2. Ice surface contours over the Lambert Glacier basin. The small squares show the positions where ice movement has been measured. 
ice thickness from echo times a standard velocity of propagation of $169 \mathrm{~m} / \mu \mathrm{s}$ was adopted. It should be noted that corrections for a higher velocity in the surface firn are most relevant in the thin ice as, for example, in the area towards the front of the Amery Ice Shelf.

\section{Surface elevation}

The map of Figure 2 shows smoothed surface elevations over the northern Prince Charles Mountains at $200 \mathrm{~m}$ spacing. The main large scale feature of the region is the generally increasing slope from the flatter convex plateau surface further inland to a zone of steepest slope in the $2000-1000 \mathrm{~m}$ range, followed by a very flat surface below $500 \mathrm{~m}$ on the Lambert Glacier. The glacier gradually merges with the ice shelf at about $90 \mathrm{~m}$ above sea-level.

The zone of steep slope is particularly important as it generally represents also the zone of maximum basal shear stress and the transition from a mode of flow with low or zero sliding to a mode with high sliding and a greatly reduced basal shear stress (cf. Budd, 1975). The general flow patterns of the ice, indicated by the orthogonals to the contours, agree well with directions of the velocities measured in the $1500-2000 \mathrm{~m}$ zone by I. F. Allison with the Australian National Antarctic Research Expeditions (A.N.A.R.E.) over the summers 1971/2 and $1973 / 4$.

\section{ICE THIGKNESS}

The maximum ice thickness measured was about $2500 \mathrm{~m}$ in the middle of the Lambert Glacier, at the confluence of the three main ice streams: Lambert, Mellor, and Fisher Glaciers. Other zones over $2000 \mathrm{~m}$ deep include the centres of the valleys of these three main glaciers further up-stream. Still further inland the ice which flows from the western side appears to be some $2000 \mathrm{~m}$ thick, whereas that flowing in from the east is closer to $\mathrm{I} 500 \mathrm{~m}$ in thickness. This picture is broken by the deep valleys and ridges of over $\mathrm{I}$ ooo $\mathrm{m}$ relief which channel the ice into the main Lambert Glacier valley.

Below the point where the Mellor and Fisher Glaciers join it, the Lambert Glacier is remarkably uniform, its thickness diminishing gradually from about $\mathrm{I}$ ooo $\mathrm{m}$ to $800 \mathrm{~m}$. Here, where it merges with the Amery Ice Shelf, the ice thins quickly to $450 \mathrm{~m}$ at the drill site GI, $62 \mathrm{~km}$ inland from the front. Thereafter the ice thickness decreases rapidly to about $200 \mathrm{~m}$ at the front of the Amery Ice Shelf, and this is believed to be associated with an increasing basal melt rate in this zone. (This will form the subject of an A.N.A.R.E. Report by various authors, edited by W. F. Budd, entitled The Amery Ice Shelf-report of the A.N.A.R.E. wintering-over program of 1968 and following summer measurements.)

\section{Bedrock Elevation}

The large-scale smooth bedrock contours are shown at $500 \mathrm{~m}$ intervals in Figure 3 . The main geomorphological feature is the basin sloping into the deep Lambert Glacier which reaches $2000 \mathrm{~m}$ below present sea-level at its confluence with the Fisher and Mellor Glaciers. It is, however, generally some $800 \mathrm{~m}$ below sea-level, a depth which extends to the continental shelf. This trend is broken by the high mountain peaks, ridges, and deep valleys which lead into the Lambert Glacier. Mt Menzies, the highest peak in the region, reaches $3300 \mathrm{~m}$ near the edge of the Fisher Glacier whose valley, which here drops to $200 \mathrm{~m}$ below sea-level, gives a relative relief of $3500 \mathrm{~m}$.

\section{io. Profiles}

Several vertical section profiles are shown in Figures 4,5 and 6 . A longitudinal profile from the front of the Amery Ice Shelf up the Lambert Glacier to the basin shows the main largescale features of the ice along a flow line. The initially low slope inland, which then inclines 


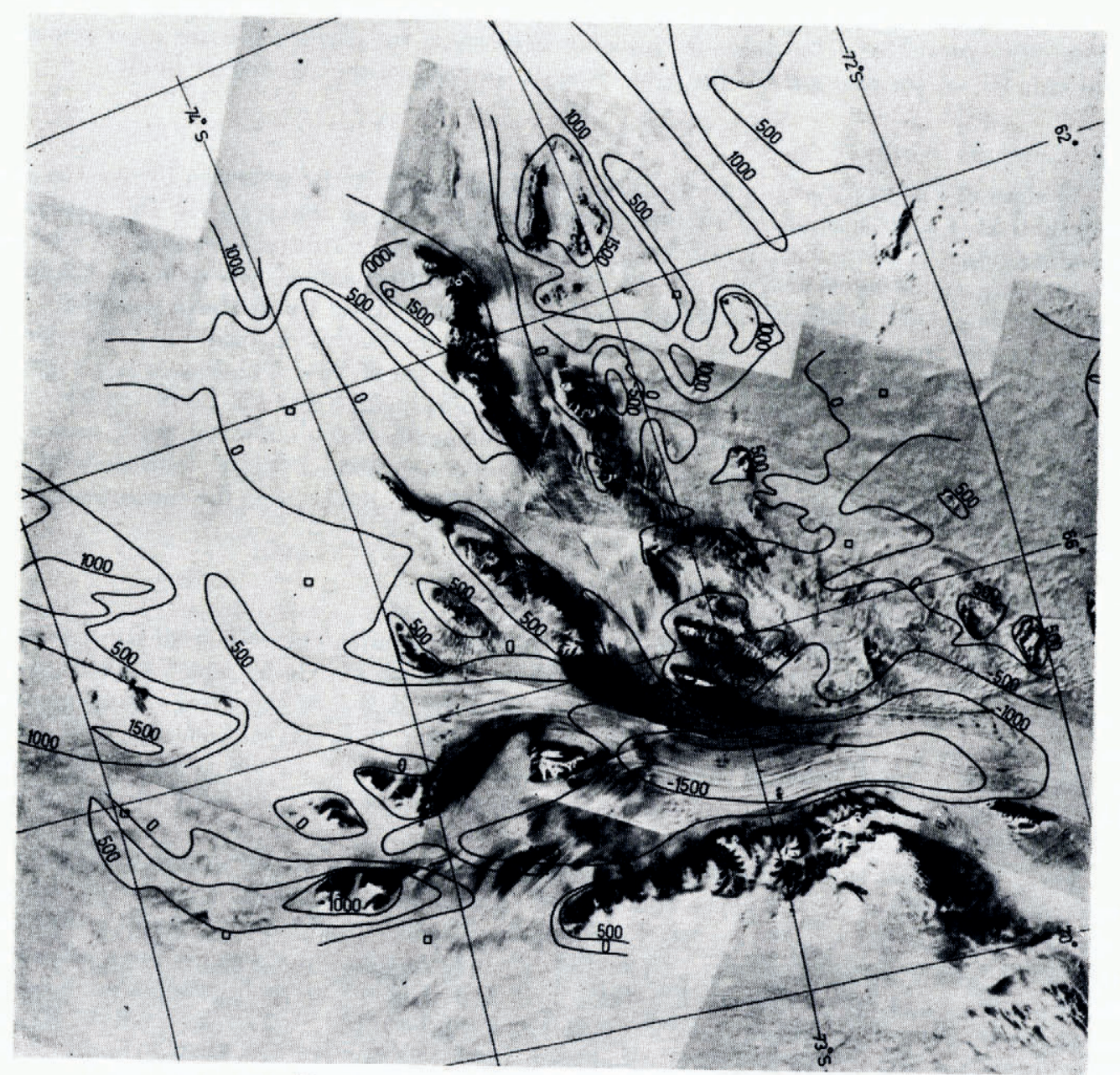

Fig. 3. Bedrock contours over the Lambert Glacier basin.

steeply into the valley glacier region, subsequently flattens over the deep confluence hollow, ending in the uniform flat surface where it flows into the Amery Ice Shelf.

A cross profile at right angles to this flow line over the confluence region is shown in Figure 5. Here the high rock edge of $\mathrm{Mt} \mathrm{Stinear,} \mathrm{with} \mathrm{maximum} \mathrm{height} \mathrm{of} \mathrm{about} \mathrm{I} 700 \mathrm{~m}$ above sea-level, plunges to the centre of the Lambert Glacier $2200 \mathrm{~m}$ below sea-level in the comparatively short distance of about $30 \mathrm{~km}$.

Figure 6 shows the similar high contrast in the region next to Mt Menzies, going north across the Fisher Glacier and south over the inland ice plateau.

\section{i i. Special features}

The most remarkable feature of the echo-sounding results is the very deep bedrock depression near the confluence of the Fisher, Mellor, and Lambert Glaciers. Deep hollows are often associated with the confluence of glaciers, of which the well known Konkordiaplatz of the Grosser Aletschgletscher in Switzerland is an example. The depression in the Lambert 


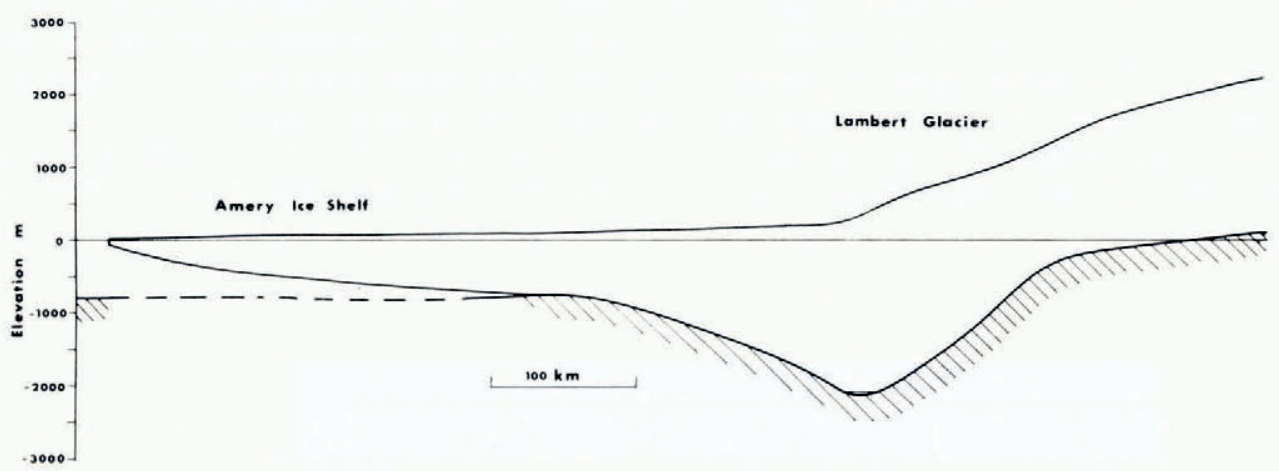

Fig. 4. Ice surface and bedrock profile along a flow line from the inland ice sheet through the Lambert Glacier to the Amery Ice Shelf and the coast. Smooth profiles were drawn from the data obtained at $3 \mathrm{~km}$ intervals.

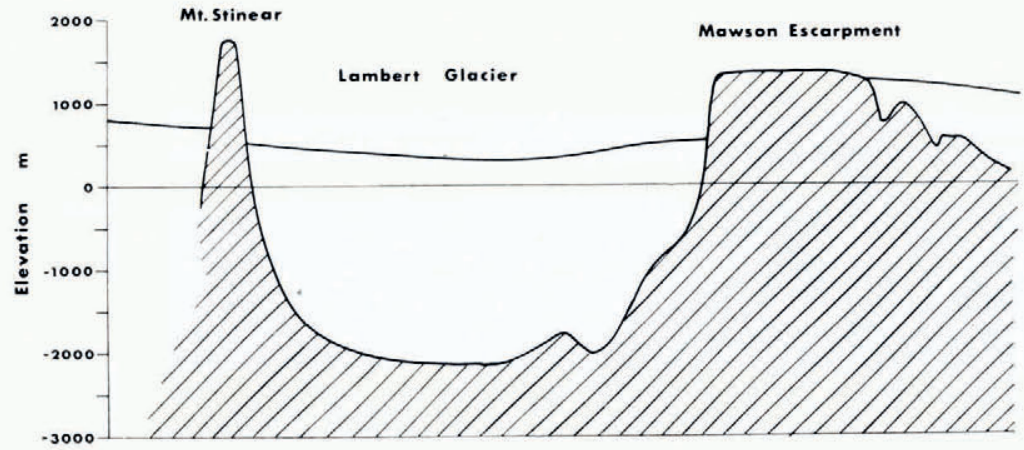

$50 \mathrm{~km}$

Fig. 5. Ice surface and bedrock profile across the deep section of the Lambert Glacier near Mt Stinear.
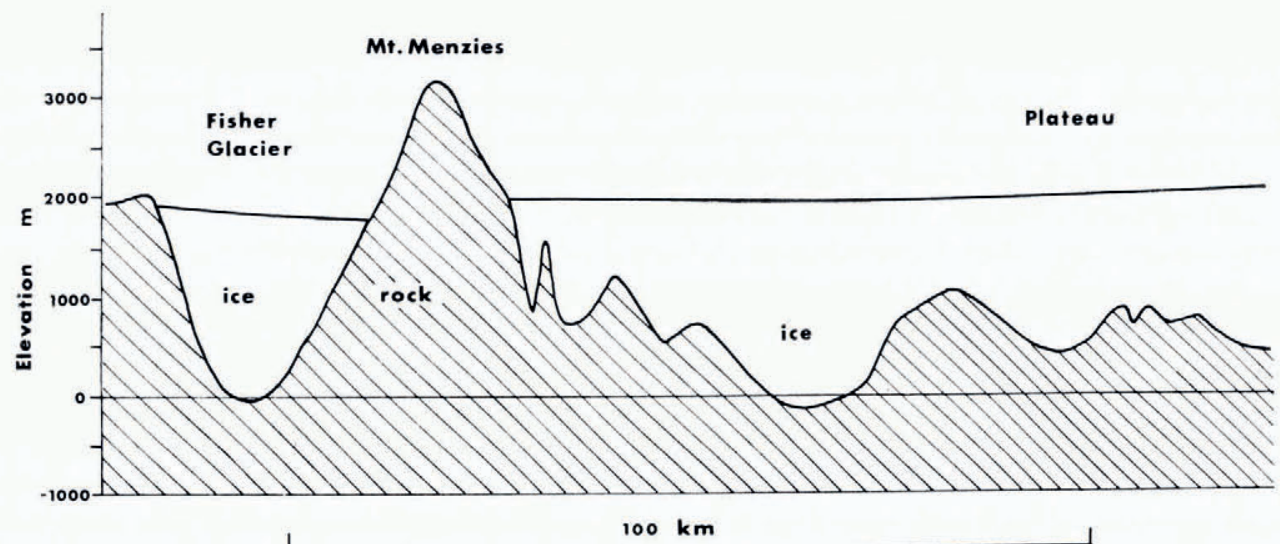

Fig. 6. Ice surface and bedrock profile across Mt Menzies, the Fisher Glacier to the north, and the plateau to the south. 
Glacier is, however, on a much greater scale. The echo strength was particularly marked across this deep section-even stronger and clearer than in neighbouring less deep regions (cf. Fig. 7). For about $15 \mathrm{~km}$ the section also showed a remarkably flat base. These considerations suggest the possibility of a basal melt lake existing in the depression. This would appear to be similar to the lakes found below the Antarctic ice sheet by Oswald and Robin (I973); the increased echo strength is similar to the effect they observed. Figure 7 shows the

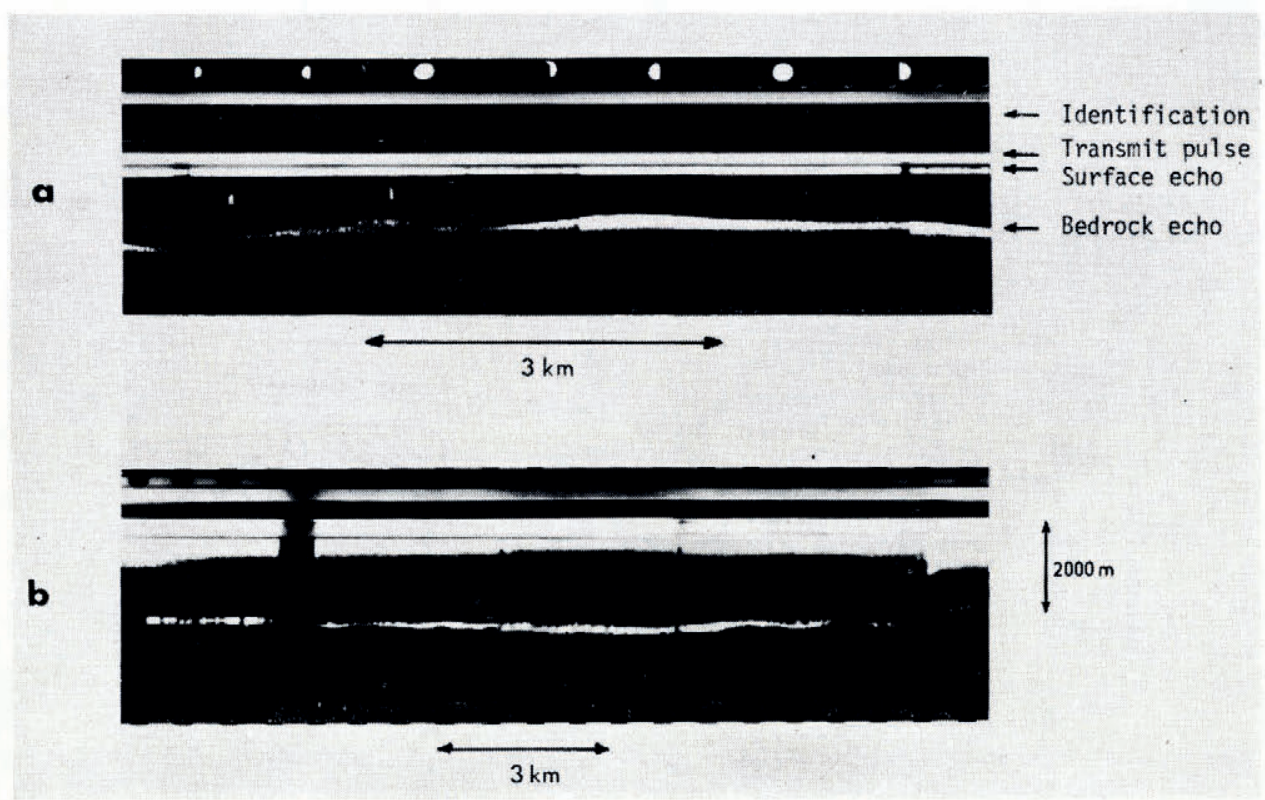

Fig. 7. Examples of ice radar film record. Not visible on these prints are the thickness calibration lines spaced at $2 \mu s$ intervals. Example $(a)$ is from a smooth, slowly moving ice region just north of Mt Cresswell (see Fig. I), while example $(b)$ is from the Lambert Glacier just down-stream of the region where it is joined by the Fisher and Mellor Glaciers and where it is suspected that there is considerable melt water. It is estimated that in regions of good echoes such as in example (a), the thickness is accurate to $\pm 10 \mathrm{~m}$. Poorer echoes increase the reading error, possibly to about $\pm 50 \mathrm{~m}$ in the worst cases.

section of the film record. It is apparent from the profile shown in Figure 4 that the bedrock has a back-slope near the bottom of more than ten times the surface slope of the ice. This is sufficient to cut off the basal water flow from the control of the surface. If this were to occur all the way around the depression, it would be sufficient to cause a melt lake.

Finally, temperature-depth calculations give definite melting-point values for the bottom of this depression. Thus the existence of a basal melt lake there seems highly likely.

\section{Acknowledgements}

The authors gladly acknowledge the help given to this project by the provision of the ERTS photography by the United States authorities. We also thank Mr I. F. Allison of the Antarctic Division for providing information on the ice movement in the Lambert Glacier Basin and the other members of the $1970-73$ ANARE for their support. 


\section{REFERENCES}

Bird, I. G., and others. In press. Radar ice so tnding at Ioo MHz, by I. G. Bird, B. Morton and A. Robinson. Melbourne, Dept. of Science, Antarctic Division. (Antarctic Division Technical Note No. 17.)

Budd, W. F. 1966. The dynamics of the Amery Ice Shelf. Fournal of Glaciology, Vol. 6, No. 45, p. 335-58.

Budd, W. F. 1975. A first simple model for periodically self-surging glaciers. Fournal of Glaciology, Vol. 14, No. 70, p. $3^{-21}$.

Budd, W. F., and others. 1967. The Amery Ice Shelf, by W. [F.] Budd, I. [H.] Landon-Smith and E. [R.] Wishart. (In Oura, H., ed. Physics of snow and ice $:$ international conference on low temperature science. . . . 1966. . . Proceedings, Vol. I, Pt. 1. [Sapporo], Institute of Low Temperature Science, Hokkaido University, p. 447-67.)

Budd, W. F., and others. [1970.] The extent of basal melting in Antarctica, by W. [F.] Budd, D. Jenssen and U. Radok. Polarforschung, Bd. 6, Jahrg. 39, Nr. 1, 1969, p. 293-306.

Budd, W. F., and others. 1971. Derived physical characteristics of the Antarctic ice sheet. Mark 1, by W. F. Budd, D. Fenssen and U. Radok. Melbourne, University of Melbourne, Meteorology Dept. (University of Melbourne. Meteorology Dept. Publication No. 18.)

Evans, S. 1970. Review of radio echo system performance. (In Gudmandsen, P., ed. Proceedings of the international meeting on radioglaciology, Lyngby, May 1970. Lyngby, Technical University of Denmark, Laboratory of Electromagnetic Theory, p. 100-02.)

Morgan, V. I. 1972. Oxygen isotope evidence for bottom freezing on the Amery Ice Shelf. Nature, Vol. 238, No. 5364 , p. $393-94$.

Oswald, G. K. A., and Robin, G. de Q. 1973. Lakes beneath the Antarctic ice sheet. Nature, Vol. 245, No. 5423, p. $25 \mathrm{I}^{-5}$.

\section{DISCUSSION}

D. J. Drewry: In view of the roughness of the terrain that you sounded, did you deconvolute the radio-ech) records?

W. F. Budd: No. So far we have only been concerned with the large-scale smooth contours to prepare the preliminary maps. For these deconvolution is not necessary.

W. F. WEEKs: Were your glacier velocities determined by radio-echo fading patterns?

BuDd: No, they were obtained by standard tellurometric surveying.

G. DE Q. RoBIN: Your earlier maps showed that the basal ice temperature was at the pressure melting point over wide areas near the coasts of Antarctica. Would you agree that it now appears that ice rises and ice that is slowly moving are likely to be frozen at the base, and that the pressure melting point is only to be attained under the more rapidly moving ice streams?

BudD: Yes. Those early Antarctic basal temperature maps are derived from a low density of data points and in most cases smooth over the small-scale coastal irregularities. However, there is still the general trend for the basal temperatures to increase towards the pressure melting point when approaching the coast and the inland boundaries of the major ice shelves.

C. W. M. Swithinbank: We would all welcome having the basal temperature maps brought up to date so that we know where to go to study sliding velocities by the technique of matching fading patterns of radio echoes. 